\title{
ROLE OF NUTRIENTS IN THE MANAGEMENT OF POSTOPERATIVE WOUND HEALING- A STUDY IN SOUTHERN ODISHA
}

\author{
${ }^{1}$ Assistant Professor, Department of General Surgery, MKCG Medical College, Berhampur. \\ ${ }^{2}$ Associate Professor, Department of General Surgery, MKCG Medical College, Berhampur. \\ $3 J$ unior Resident, Department of General Surgery, MKCG Medical College, Berhampur. \\ ${ }^{4}$ Senior Resident, Department of General Surgery, MKCG Medical College, Berhampur. \\ $5 J u n i o r$ Resident, Department of General Surgery, MKCG Medical College, Berhampur. \\ ${ }^{J}$ unior Resident, Department of General Surgery, MKCG Medical College, Berhampur.
}

Bipin Kishore Bara ${ }^{1}$, Sibaprashad Pattanayak², Binoy Kumar Maharana 3 , Manoj Kumar Behera 4 , Tapan Kumar Malla 5 , Manish Kumar 6

\begin{abstract}
BACKGROUND

Nutrition deficiencies are prevalent and cause delayed wound healing in patients with wounds (both surgical and non-surgical). Exact role of nutritional supplements in management of wounds remain uncertain. This study was carried out to compare postoperative complication and outcome in patients who were admitted to undergo elective surgical interventions and role of oral nutritional supplements in it.
\end{abstract}

\section{MATERIALS AND METHODS}

A randomised controlled trial was conducted in Department of General Surgery, MKCG Medical College, Berhampur, Ganjam, Odisha, India. Duration of study was 1 year, carried out between July 2016 and June 2017. During the study period only 50 patients fulfilled the inclusion criteria and gave their verbal consent, so they were included in the study. Final sample size was 50 (convenient sampling). After patients were admitted in indoor for their elective surgery, they were randomly allocated in con trol (Group A) and study (Group B) according to their indoor registration number. Even numbers were allotted to control and odd numbers to study group. Pre- and post-operative oral nutritional supplements were given in study (Group B) group and was compared with control group (who did not receive any oral nutritional supplements) in terms of gastrointestinal complications, wound complication and period of hospital stay.

\section{RESULTS}

Local postoperative wound complications were found to be more in the control group than study group. Similarly, gastrointestinal complications like abdominal cramps, distention, diarrhoea and vomiting were found to be more in control group; 20 (80\%) patients of study Group B had no post-surgical wound complication and 18 (72\%) patients of study Group B had no gastrointestinal complications. The patients of study Group B were discharged within 7 - 10 postoperative days, whereas control Group A patient had to stay at hospital for a prolonged period and were discharged in between $20^{\text {th }}-25^{\text {th }}$ postoperative day.

\section{CONCLUSION}

Preoperative and postoperative Oral Nutritional Supplements as studied helps in wound healing. Micro- and macro-nutrients are essential for tissue repair and good skin condition. Such approach reduces postoperative wound and gastrointestinal complication, early wound healing and even duration of hospital stay and cost.

\section{KEYWORDS}

Oral Nutritional Supplements, Postoperative Wound Healing, Complications, Hospital Stay.

HOW TO CITE THIS ARTICLE: Bara BK, Pattanayak S, Maharana BK, et al. Role of nutrients in the management of postoperative wound healing- a study in southern Odisha. J. Evolution Med. Dent. Sci. 2017;6(87):5981-5984, DOI: 10.14260/jemds/2017/1301

\section{BACKGROUND}

Odisha is a developing state in eastern India and its southern part is an endemic zone for malnutrition, specifically due to lack of balanced diet. Balanced diet includes adequate amount of macronutrients like protein, carbohydrate, fat and required amount of micronutrients like vitamin $\mathrm{A}, \mathrm{B}, \mathrm{C}, \mathrm{D}, \mathrm{E}$, $\mathrm{K}$, calcium, copper, iron, selenium, zinc and water, etc. As
\end{abstract}

'Financial or Other Competing Interest': None.

Submission 22-09-2017, Peer Review 18-10-2017,

Acceptance 24-10-2017, Published 30-10-2017.

Corresponding Author:

Dr. Binoy Kumar Maharana,

Junior Resident, Department of General Surgery,

MKCG Medical College and Hospital,

Berhampur, Odisha.

E-mail: drbinoy2009@gmail.com

DOI: $10.14260 /$ jemds $/ 2017 / 1301$

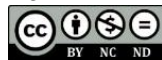

wound healing is a complex phenomenon starting from inflammation to collagen formation, neovascularisation and finally the formation of scar tissue, adequate nutrition is required at different stages of wound healing like cell proliferation, cell repair, chemotactic factors (Cytokines, growth factors), cell division, cell movement at wound site etc. Similarly, adequate amount of nutrient is required for synthesis of nucleic acid (DNA, RNA), tissue maturation and differentiation.

Protein is required for tissue growth, cell renewal and repair after injury. ${ }^{1}$ It plays a major role in wound healing in stages of haemostasis, inflammation and granulation tissue formation, cell proliferation, tissue reorganisation, RNA and DNA synthesis, collagen and elastic tissue formation and keratinisation. Nitrogen balance is important in case of wound healing. ${ }^{2}$ Similarly, deficiency of amino acids like cysteine, proline affects neo-angiogenesis, fibroblastic 
response, collagen synthesis, wound remodelling and tissue strength, whereas cysteine, cystine, methionine, arginine, lysine, histidine and glycine delays the wound healing. ${ }^{3}$ Arginine supplements also enhances collagen deposition and wound strength..$^{4,5}$

Carbohydrate is the main source of energy. Fibroblast proliferation is sensitive to glucose deficiency. ${ }^{6}$ Lipid and essential fatty acid provide energy for proliferation and help in building of epidermal and dermal tissue. They help in cell membrane synthesis and intracellular matrix synthesis.

Micronutrients in physiological limits are essential in wound healing process.

1. Vitamin A in optimum dose is essential in epidermal proliferation and reepithelialisation, in inflammatory phase of wound healing and it has great ability to reverse the corticosteroid induced inhibition of wound healing. In fact, vitamin A in 25000 IU/day is recommended for chronic corticosteroid users, diabetic mellitus, seriously injured patients and in chemotherapy or radiotherapy patients.

2. B-complex is essential in cell proliferation, maintain healthy skin, maintain muscle tone and increased metabolic rate enhances immune and nervous system function.

3. Vitamin $\mathrm{C}$ is a cofactor for collagen synthesis. It is also a powerful reducing agent for oxygen radicals and an electron donor for several enzymes. Its deficiency may lead to collagen defect, defective fibroblast response and scar tissue formation. 7,8

4. Vitamin D and Calcium are collectively involved in cartilage and bone remodelling, neuromuscular and immune function. ${ }^{9}$

5. Vitamin E acts as an antioxidant interacting with the Selenium-dependant glutathione oxidase to inhibit degradation of cell membrane fatty acids. ${ }^{7}$

6. Vitamin $\mathrm{K}$ is important in haemostatic phase of wound healing and its deficiency may result in haemorrhage, impaired wound repair and infection. ${ }^{10,11}$

Calcium promote basal cell proliferations in epidermis and contributes to homeostasis. ${ }^{7}$ Likewise, its low serum level leads to defective collagen and elastin tissue formation.

Iron deficiency interferes with wound healing through tissue hypoxia and decreased bactericidal ability of leucocytes. ${ }^{12,13}$

Selenium is a free radical scavenger and it protects biological membrane. ${ }^{14}$ It also increases immunity. ${ }^{15}$

Zinc is a cofactor for many enzymes required in wound healing like DNA and RNA polymerase, proteases and carbonic anhydrase.7,16 Study shows that topical zinc is better than oral supplement as $1 \%$ zinc oxide cream increases mitotic and re-epithelialisation rate. ${ }^{7}$

\section{MATERIALS AND METHODS}

This randomised controlled trial was carried out in the Department of General Surgery, MKCG Medical College, Berhampur, Odisha, India for 1 year from July 2016 to June 2017. The randomisation was done after admission of patients.

The Patients were Selected according to the following Inclusion Criteria-
1. Patients admitted to undergo elective surgery in the Department of General Surgery.

2. Patients with no other co-morbid conditions like diabetes mellitus, hypertension or tuberculosis.

3. Patients with haemoglobin level $>10$ gram $\%$, serum protein $>6$ gram $/ \mathrm{dL}$ and serum albumin $>3$ gram $/ \mathrm{dL}$.

4. Patients who gave consent.

\section{Exclusion Criteria}

1. Age less than 20 years and more than 60 years.

2. Patients with co-morbid conditions like diabetes mellitus, hypertension, HIV, asthma, tuberculosis or cancer.

3. Pregnancy.

4. Severely malnourished patients.

5. Patients not willing to participate in the study.

6. Patients undergoing emergency surgery.

During the study period of 1 year only 50 patients fulfilled the inclusion criteria and gave their verbal consent, so they were included in the study. Final sample size was 50 (convenient sampling). After patients were admitted in indoor for their elective surgery, they were randomly allocated in control (Group A) or study (Group B) according to their indoor registration number. Even numbers were allocated in control group (Group A) and odd numbers in study (Group B) group. Even indoor registration numberControl group (Group A). Odd indoor registration numberStudy group (Group B).

Then they were explained about the nature of the study. But they were not aware in which group they were included during the study. Patients admitted were thoroughly examined and name, age, sex and socioeconomic status were noted down. Examination like Haemoglobin, DC (Differential Count), TLC (Total Leucocyte Count), FBS (Fasting Blood Glucose), PPBS (Postprandial Blood Glucose), Serum (urea, creatinine, protein, albumin, $\mathrm{Na}^{+}, \mathrm{k}^{+}, \mathrm{Ca}^{2+}$ ) etc. were done routinely. These patients were randomly allotted by chance to control (A) group and study (B) group according to the indoor registration number; 25 persons with even indoor registration number were in control group (Group A) and 25 persons with odd indoor registration number were in study group (Group B). Normal protocols were followed after admission of the patients. Fluid restriction, IV antibiotics, analgesics and Proton Pump Inhibitors were given as needed. Regular dressings were done to both the groups in postoperative period.

In addition, Group B (study group) patients received oral nutritional supplements of protein, carbohydrate, fat and multivitamins and minerals 7 days prior to the operation till the day before operation and within 48 hours post operation (after bowel movement) till their discharge from hospital. Dressing of the wound was done on $4^{\text {th }}$ day and every alternate day or daily as per requirement till their discharge from the hospital.

The Results Obtained were Statistically Evaluated and Compared with each Group and Analysed under the Following Points-

1. Number of days required for wound healing.

2. Discharge from wound like serous, serosanguinous or purulent to be noted. 
3. Culture and sensitivity test.

4. Wound dehiscence.

5. Presence of GI disturbances like abdominal cramp and distension, diarrhoea and vomiting.

The variables obtained were compared using frequency, percentage, chi-square test, independent t-test and p-value was obtained. These data set was statistically analysed using software Statistical Package for the Social Sciences (SPSS) Version 16. A p-value of $<0.05$ was considered significant, while $p$-value of $>0.05$ was considered not significant.

\section{RESULTS}

The study included 50 patients. The mean age was 45.3 years. The patients aged between 20 to 60 years were included in this study. Majority of patients were in 40 - 50 years' age, 34 were males and 16 were females.

Post-surgical wound infection like wound dehiscence, serous collection, serosanguinous/ purulent discharge was found to be less in the study group than the control group (Table 1). Wound dehiscence occurred in $4(16 \%)$ patients of control group, whereas $0(0 \%)$ patients had wound dehiscence in study group; 20 (80\%) patients of study Group B had no post-surgical wound complication, whereas only 9 (36\%) patients of control Group A had no post-surgical wound complication. The result obtained was analysed by chi-square test. It was found to be significant in study Group B who received oral nutritional supplements of protein, carbohydrate, fat and multivitamins and minerals 7 days prior to the operation and within 48 hours post-operation (after bowel movement) till their discharge $(p=0.0001)$ (Table 1).

\begin{tabular}{|c|c|c|c|}
\hline Complication & $\begin{array}{c}A=\text { Control } \\
\text { Group } \\
(\mathrm{N}=25)\end{array}$ & $\begin{array}{c}\text { B= Study } \\
\text { Group } \\
(N=25)\end{array}$ & $\begin{array}{c}\text { P value, } \\
\text { Chi-Square } \\
\text { Test }\end{array}$ \\
\hline Serous Collection & $16(64 \%)$ & $05(20 \%)$ & \multirow{5}{*}{$\begin{array}{c}\mathrm{p}=0.0001 \\
\text { chi-square= } \\
62.90\end{array}$} \\
\hline $\begin{array}{l}\text { Serosanguineous/ } \\
\text { Purulent Discharge }\end{array}$ & $08(32 \%)$ & $02(8 \%)$ & \\
\hline Wound Dehiscence & $04(16 \%)$ & $00(00 \%)$ & \\
\hline No Complication & $09(36 \%)$ & $20(80 \%)$ & \\
\hline Total & 37 & 27 & \\
\hline & Iraical W & d Compl & tion \\
\hline
\end{tabular}

Some patients had more than one complication, which is why the total is 37 in control and 27 in study group which is more than $\mathrm{N}(25)$ in Table 1.

Gastrointestinal disturbances like abdominal cramps and distension occurred in 10 (40\%) patients of control Group A and in $5(20 \%)$ patients of study Group B. Similarly, diarrhoea occurred in $4(16 \%)$ patients of control Group A and in 2 (08\%) patients of study Group B. Likewise, vomiting occurred in 7 (28\%) patients of control Group A and $3(12 \%)$ patients of study Group B. There was no gastrointestinal complication in $18(72 \%)$ patients of study Group B and 11 (44\%) patients of control Group A; 1 (4\%) patient of study Group B and 3 (12\%) patients of control Group A had all the 3 gastrointestinal complications like abdominal cramp, distention, diarrhoea and vomiting. Analysis of result was carried out using Chi-square test and was found to be significant $(p=0.00023)$ (Table 2).

\begin{tabular}{|c|c|c|c|}
\hline $\begin{array}{l}\text { Gastrointestinal } \\
\text { Complication }\end{array}$ & $\begin{array}{c}A=\text { Control } \\
\text { Group } \\
(\mathrm{N}=25)\end{array}$ & $\begin{array}{c}\text { B= Study } \\
\text { Group } \\
(\mathrm{N}=25)\end{array}$ & $\begin{array}{c}\text { P Value, } \\
\text { Chi-Square } \\
\text { Test }\end{array}$ \\
\hline $\begin{array}{l}\text { Abdominal Cramp } \\
\text { and Distension }\end{array}$ & $10(40 \%)$ & $05(20 \%)$ & \multirow{3}{*}{$p=0.00023$} \\
\hline Diarrhoea & $04(16 \%)$ & $02(8 \%)$ & \\
\hline Vomiting & $07(28 \%)$ & $03(12 \%)$ & \\
\hline $\begin{array}{c}\text { No Gastrointestinal } \\
\text { Complication }\end{array}$ & $11(44 \%)$ & $18(72 \%)$ & \multirow{2}{*}{$\begin{array}{l}\text { chi-square } \\
=24.13\end{array}$} \\
\hline Total & 32 & 28 & \\
\hline
\end{tabular}

Some patients had more than one complication, which is why the total is 32 in control and 28 in study group which is more than $\mathrm{N}(25)$ in Table 2.

However, in case of number of days of hospital stay it is less in case of study Group (B) than in case of control Group (A). Average number of days of hospital stay in control Group A was 23.32 days and in study group it was 8.14 days (Table $3)$. The result was analysed using Independent sample t-test and was found to be significant $(\mathrm{p}=0.00012)$ (Table 3).

\begin{tabular}{|c|c|c|c|}
\hline & $\begin{array}{c}\text { Control Group } \\
\text { (N= 25) }\end{array}$ & $\begin{array}{c}\text { Study Group } \\
\text { (N= 25) }\end{array}$ & $\begin{array}{c}\text { P Value } \\
\text { (Independent } \\
\text { Sample t-test) }\end{array}$ \\
\hline $\begin{array}{c}\text { Number of } \\
\text { Days } \\
\text { of Hospital } \\
\text { Stay }\end{array}$ & $\begin{array}{c}20-25 \\
\text { Mean= 23.32 }\end{array}$ & $\begin{array}{c}7-10 \\
\text { Mean }=8.14\end{array}$ & $\mathrm{P}=0.00012$ \\
\hline \multicolumn{3}{|c|}{ Table 3. Number of Days of Hospital Stay } \\
\hline
\end{tabular}

A small sample size was the limitation of the above study. This arose due to implementation of all the exclusion criteria during the study strictly. A randomised controlled trial with a larger sample size may have helped to strengthen the findings or may have revealed variation.

\section{DISCUSSION}

Preoperative oral nutritional supplements consisting of lipid, carbohydrate, multivitamins and multiminerals given to a patient undergoing elective surgery helps in reducing the postoperative wound complications. As per the international guideline, Oral Nutritional Supplements should be given for 10 - 14 days prior to surgery in a malnourished patient. In our study, we had given Oral Nutritional Supplements 1 week before surgery which was better tolerated by patient than any parenteral nutrition.

The above study indicated that Oral Nutritional Supplements is effective in reducing the postoperative wound complications. There was no gastrointestinal complication in $18(72 \%)$ patients of study Group B in comparison to control Group A, where 11 (44\%) patients had no gastrointestinal complication. There was no wound complication in 20 (80\%) patients of study Group B in comparison to control Group A, where only $09(36 \%)$ patients had no wound complication. This study was also compared with a similar study of Makela et al, who found that anastomotic leak was more in control group of left-sided colon cancer, which was also proved by 
another study; Gregg et al who studied on early postoperative death in control group in bladder cancer who were without Oral Nutritional Supplements. ${ }^{17,18}$ Again our study was supported by Hubbard et al, who reviewed 46 studies of all types with 4328 patients in which compliance to Oral Nutritional Supplements was measured. ${ }^{19}$

\section{CONCLUSION}

Preoperative and postoperative Oral Nutritional Supplements as studied has an intrinsic link between nutrition and wound healing. The micro- and macro-nutrients along with carbohydrate and lipid are essential for tissue repair and good skin condition. Such approach reduces the postoperative gastrointestinal complication, early wound healing and even the duration of hospital stay and cost.

\section{REFERENCES}

[1] Munro HN. Report of a conference on protein and amino-acid needs for growth and development. Am J Clin Nutr 1974;27:55-8.

[2] Levenson SM, Demetriou AA. Metabolic factors. In: Cohen IK, Diegelmann R, Lindblad WJ, (eds). Wound healing: biochemical and clinical aspects. Philadelphia: Saunders, 1992:248-73.

[3] Altschul AM. Fortification of foods with amino-acids. Nature 1974;248(5450):643-6.

[4] Stechmiller JK, Childress B, Cowan L. Arginine supplementation and wound healing. Nutr Clin Pract 2005;20(1):52-61.

[5] Witte MB, Barbul A. Arginine physiology and its implication for wound healing. Wound Repair Regen 2003;11(6):419-23.

[6] Han J, Hughes MA, Cherry GW. Effect of glucose concentration on the growth of normal human dermal fibroblasts in vitro. J Wound Care 2004;13(4):150-3.

[7] Lansdown AB. Nutrition 2: a vital consideration in the management of skin wounds. $\mathrm{Br} J$ Nurs 2004;13(20):1199-210.

[8] Bourne GH. Effect of vitamin C deficiency on experimental wounds: tensile strength and histology. Lancet 1944;243(6300):688-92.
[9] Tavera-Mendoza LE, White JH. Cell defenses and the sunshine vitamin. Sci Am 2007;297(5):62-72.

[10] Goskowicz M, Eichenfield LF. Cutaneous findings of nutritional deficiencies in children. Curr Opin Pediatr 1993;5(4):441-5.

[11] Jenkins ME, Gottlschlich MM, Kopcha R, et al. A prospective analysis of serum vitamin $\mathrm{K}$ in severely burned pediatric patients. J Burn Care Rehabil 1998;19(1 Pt 1):75-81.

[12] Alvarez OM, Mertz PM, Eaglstein WH. The effect of the proline analogue 1-azetidine-2-carboxylic acid (LACA) on epidermal and dermal wound repair. Plast Reconstr Surg 1982;69(2):284-9.

[13] Knighton DR, Silver IA, Hunt TK. Regulation of wound healing angiogenesis: effect of oxygen gradients and inspired oxygen concentration. Surgery 1981;90(2):262-70.

[14] Tappel AL. Free radical lipid peroxidation damage and its inhibition by vitamin E and selenium. Fed Proc 1965;24:73-8.

[15] Rojas AI, Phillips TJ. Patients with chronic leg ulcers show diminished levels of vitamins A and E, carotenes, and zinc. Dermatol Surg 1999;25(8):601-4.

[16] Occleston NL, Tarnuzzer RW, Burslem F, et al. Matrix metalloproteinases: an essential component of cell mediated collagen contraction. Presented at: fifth annual meeting of the European tissue repair society, Padova, Italy; 1995.

[17] Makela JT, Kiviniemi H, Laitinen S. Risk factors for anastomotic leakage after left-sided colorectal resection with rectal anastomosis. Dis Colon Rectum 2003;46(5):653-60.

[18] Gregg J, Cookson MS, Philips S, et al. Effect of preoperative nutritional deficiency on mortality after radical cystectomy for bladder cancer. J Urol 2011;185(1):90-6.

[19] Hubbard GP, Elia M, Holdoway A, et al. A systematic review of compliance to oral nutritional supplements. Clin Nutr 2012;31(3):293-312. 